University of Wollongong

Research Online

Faculty of Informatics - Papers (Archive)

Faculty of Engineering and Information

Sciences

September 2007

\title{
Why Build a Customer Relationship Management Capability?
}

T. R. Coltman

University of Wollongong, tcoltman@uow.edu.au

Follow this and additional works at: https://ro.uow.edu.au/infopapers

Part of the Physical Sciences and Mathematics Commons

\section{Recommended Citation}

Coltman, T. R.: Why Build a Customer Relationship Management Capability? 2007.

https://ro.uow.edu.au/infopapers/569

Research Online is the open access institutional repository for the University of Wollongong. For further information contact the UOW Library: research-pubs@uow.edu.au 


\title{
Why Build a Customer Relationship Management Capability?
}

\author{
Abstract \\ The market enthusiasm generated around investment in CRM technology is in stark contrast to the \\ naysaying by many academic and business commentators. This raises an important research question \\ concerning the extent to which companies should continue to invest in building a CRM capability. Drawing \\ on field interviews and a survey of senior executives, the results reveal that a superior CRM capability can \\ create positional advantage and subsequent improved performance. Further, it is shown that to be most \\ successful, CRM programs should focus on latent or unarticulated customer needs that underpin a \\ proactive market orientation. \\ Keywords \\ Customer relationship management; Technology investment; Performance \\ Disciplines \\ Physical Sciences and Mathematics

\section{Publication Details} \\ This article was originally published as Coltman, TR, Why Build a Customer Relationship Management \\ Capability?, Journal of Strategic Information Systems, 2007, 16(3), 301-320. Copyright 2007 Elsevier. The \\ journal homepage is available here.
}




\section{Why Build a CRM Capability When So Many Appear to Fail?}

\section{Tim Coltman}

School of Information Technology and Computer Science

University of Wollongong,

NSW, Australia

Email: tcoltman@uow.edu.au 


\title{
Why Build a Customer Relationship Management Capability?
}

\begin{abstract}
The market enthusiasm generated around investment in CRM technology is in stark contrast to the naysaying of many academic and business commentators. This raises an important research question concerning the extent to which companies should continue to invest in building a CRM capability. Drawing on field interviews and a survey of senior executives, the results reveal that a superior CRM capability can create positional advantage and subsequent improved performance. Further, it is shown that to be most successful, CRM programs should focus on latent or unarticulated customer needs that underpin a proactive market orientation.
\end{abstract}

Keywords: Customer relationship management, technology investment, performance

\section{INTRODUCTION}

The contribution of information technology (IT) to business performance has been under scrutiny for more than two decades (for a review see Chan, 2000). During this time various models of IT performance have been developed to show that IT: impacts organizational performance via intermediate business processes (Davenport, 1993; Barua et al., 1995); requires complementary organizational resources such as workplace practices and structures (Powell \& Dent-Medcalfe, 1997; Ray et al., 2005); is influenced by the external environment (Hunter, et al., 2003); and as a construct, should be disaggregated into meaningful components (Sethi \& Carraher, 1992). The received wisdom from this extensive body of work indicates that organizations in all sectors of industry, commerce and government can generate business value when appropriate IT is applied in the right way (Melville et al., 2004).

In recent times, vendors have been quick to point out that one of the "right ways" is to invest in customer relationship management (CRM) technologies. The argument put forward 
is that many firms have managed to punch above their weight in today's competitive environment by using technology to identify profitable customers and then customize marketing on the basis of customer value. Some of the stellar examples that come to mind include: National Australia Bank in Australia, Otto Versand in Germany, Tesco in the United Kingdom, Travelocity.com, Capital One and Harrah's Entertainment in the United States of America. In each case, these firms have chosen to compete through superior customer relating capabilities (knowledge, relationships, insight etc.) based largely on the CRM programs deployed.

However, the enthusiasm generated around CRM and a select concentration of "relationship winners" is in stark contrast to most firms "that have not yet realized the benefits of acquiring these expensive systems" (Kumar \& Reinartz, 2006 p. xxi). For example, research and advisory firm the Gartner Group, claim that close to 50\% of all CRM projects failed to meet expectations (The Australian, 8th July, 2003). Additionally, an InfoWorld (2001) survey of chief technology officers found that close to $30 \%$ of respondents in this role said that CRM was one of the most "over hyped" technologies they had seen. A follow-up survey of IT executives from large companies found that 43 per cent who have deployed CRM still believe it deserves the bad press. These commentaries highlight the frustration many executives experience as software glitches, poorly trained staff and disparate legacy systems continue to hinder effective deployment of CRM programs. Far from improving profits and cementing relationships, most companies found that new IT systems did not add any value to what was already being offered (Kumar \& Reinartz, 2006) or in the worst case scenario, CRM systems alienated long-term customers and employees (Rigby et al., 2002).

\section{So what, if anything, is wrong with CRM programs?}

In tackling this question one should be mindful of the scholarly challenge presented by the fact that the exact meaning of CRM is still subject to a wide range of views. For example, in 
a series of interviews with executives, Payne and Frow (2005) found that to some respondents CRM meant direct mail, a loyalty scheme, help desk and call centre. Other respondents envisioned CRM as a data warehouse, data mining, e-commerce solution or databases for sales force automation.

Grabner-Kraeuter and Moedritscher (2002) and Reinartz et al., (2004) suggest that one reason for the disappointing results of many CRM initiatives can be attributed to the overemphasis on CRM as an IT solution and the absence of a strategic framework for CRM success. To position the role of CRM in this paper, Payne and Frow's (2005 p.168) process oriented perspective is adopted where CRM is defined as: "the cross-functional integration of processes, people, operations, and marketing capabilities that is enabled through information, technology and applications." This definition requires a multidimensional strategic approach to CRM.

The resource based view (RBV) provides a suitable multidimensional perspective to the application of CRM because it attempts to link superior firm performance to the various resources and capabilities possessed by firms. The RBV school of thought has spread throughout strategic management (Amit \& Shoemaker, 1993; Barney, 1991; Grant, 1996; Teece et al. 1997; Wernerfelt, 1984) and more recently, the information systems (IS) literatures (Mata et al., 1995; Powell \& Dent-Medcalfe, 1997; Ray et al., 2005; Rivard et al., 2006). Although the RBV literature is not without its critics (Priem \& Butler, 2001; Williamson, 1999), the literature shares one important point: "capabilities represent the ability of the firm to combine efficiently a number of resources" (Dutta et al., 2005 p.278).

In this paper a CRM capability represents deliberate and persistent investments in a combination of human, technical and business related capabilities. These capabilities on their own are difficult to measure because they are nested within an intricate organizational system 
of interrelated and interdependent processes. This requires managers to orchestrate a combination of IT infrastructure, human skills and business structures and incentives.

Furthermore, a key premise of the RBV is that resource and capability development is selective and path dependent. This view is entirely consistent with what is known about IT business value (Melville et al., 2004; Ray et al., 2005) and CRM program success according to a series of studies conducted by Day $(2002 ; 2003)$. These authors show that there is considerable anecdotal evidence to suggest that the development of a CRM program is a selective process in that firms decide whether to make these programs the central thrust of their strategy or a subordinate element.

The remaining sections set about testing a general framework for CRM performance which explains why, and through which mechanisms, the adoption of a higher order CRM capability should lead to positions of advantage and improved firm performance. The importance of these measures is examined using field interviews and a survey of 100 senior executives. Results reveal that an adroit combination of human, technological and business capabilities is required to successfully achieve positional advantage. Further, it is shown that to be successful, CRM programs must be feasible, requiring a wider understanding of the structural and behavioral limits to organizational alignment. Perhaps most importantly, high performing companies are not overly concerned with traditional positioning strategies that focus on reactive responses to expressed needs. Instead, they seek to position around a proactive orientation that directs attention towards latent or unarticulated demand. This finding is particularly encouraging for CRM and suggests a promising future for the more the powerful analytic tools and data warehousing systems that can support a proactive market orientation. Finally, by integrating three different schools of thought into this study a more managerially relevant and theoretically important view of CRM performance is presented.

\section{THEORETICAL BACKGROUND}


Although the term CRM first surfaced in the IT vendor and practitioner community during the mid 1990s, the customer relationship concept can be traced to the 1950s when Drucker (1954) argued that customers should be the foundation of an organization and the very reason for its existence. Others have subsequently extended upon this core idea creating what is now known as the marketing concept (Kohli \& Jaworski, 1990; Narver \& Slater, 1990) and a widespread belief that customer relationship activity is an essential part of everyday management practice.

The link between customer-relationship activity and improved firm performance has received empirical support based on measures of stock price (Fornell et al. 2006), customer loyalty (Reichheld \& Teal, 1996) and market orientation (for a review see Langerak, 2003). However, preliminary work in this area has also been tempered by results that stress the importance of moderating effects (Reinartz \& Kumar, 2000). Thus, "it is probably not true that more relationship building is always better; rather, building the right type of relationship (which depends on situational factors) is critical" (Reinartz et al., 2004 p.294). Building the right type of relationship is the essence of CRM and both concepts have been used interchangeably (Parvatiyar \& Sheth, 2001; Zablah et al., 2003).

Although recent work has found that IT can enhance the performance of customer service processes (Ray et al., 2005), a common misunderstanding among academics and practitioners is that they frequently associate CRM with technology based solutions (Ryals \& Payne, 2001). Indeed, the negative reaction to CRM we have witnessed in the popular press appears to have more to do with the IT dependent view of the world rather than a failure in the importance of customer relationship value (Kumar \& Reinartz, 2006). Hence, it is not surprising that many CRM efforts have failed to meet initial expectations of the companies implementing them. 
In recent times the information systems literature has also been quick to point out that a narrow focus on technology as a source of sustained performance-such as that recently assumed in the business press (Carr, 2003)—is misguided and misleading (Piccoli \& Ives, 2005). In other words, strategic IT consists of a program of activity, dependent upon IT at its base, but encompassed within a wider system that includes human capabilities and organizational structures. This position aligns well with the RBV of the firm-a theory that has received much attention in the IT and IS literature of late (Bharadwaj, 2000; Rivard et al., 2006; Santhanam \& Hartono, 2003; Watjatrakul, 2005; Zhu, 2004; Zhu \& Kraemer, 2002). An illustrative example of this work has shown that market leaders are characterised by the "synergistic combination of IT resources ... with other organizational resources and capabilities" (Bharadwaj, 2000:186).

\section{MODEL STRUCTURE}

The focus for measuring the impact of CRM programs on the performance of the firm was originally derived from a model of competitive advantage developed by Day and Wensley (1988). Their model was an important precursor to the RBV in strategy and has become a benchmark for publications in marketing that have sought to explain performance differences between companies (Hunt \& Morgan, 1995). Day and Wensley's framework (see figure 1) conceptualizes competitive advantage as a causal chain that runs from sources of advantage (superior skills, superior resources) through positional advantages (superior customer value, lower relative costs), to performance outcomes (satisfaction, loyalty, market share, profitability).

\section{$<$ Insert Figure 1 here >}

The relatively simple deterministic relationship proposed is particularly relevant to an assessment of CRM performance for several reasons. First, it captures the importance of 
combining technological resources, human skills and business processes in a way that makes for a superior CRM capability. Second, their framework recognizes the mediating impact that positional advantage has on performance. Although alternative orientations (for example, production and innovation) exist, the marketing literature is unambiguous in its claim that a highly developed customer or market orientation will improve performance (Narver, et al. 2000). Lastly, the linear relationship proposed is "fraught with uncertainty and distorted by feedback, lags and structural rigidities" (Day \& Wensley, 1988 p.2). This enables us to explore "people issues" related to employee engagement, change management and general CRM implementation. These areas have been widely neglected in the CRM literature (Kale, 2004).

\section{RESEARCH QUESTIONS}

The approach proposed is of theoretical and practical importance because it underlies the extent to which CRM program success is determined by strategy formulation and strategy implementation. All important constructs and their hypothesized relationships are shown schematically in Figure 2.

$$
<\text { Insert figure } 2 \text { here }>>
$$

In developing a CRM capability, this study draws on prior work in marketing and IT. In the marketing literature Day and Van Den Bulte (2002) have defined a customer relating capability based on three antecedent capabilities: (1) orientation to represent the firm's values, behaviours and mindset, (2) information to reflect the availability, quality, and depth of information about customer relationships and usage of CRM technology, and (3) configuration as the supporting structures, incentives and controls. Kumar and Reinartz (2006) have suggested that a CRM strategy requires four components: (i) a customer management orientation, (ii) integration and alignment of organizational processes, (iii) information capture and alignment of technology, and (iv) CRM strategy implementation. 
Both approaches are similar and imply that an effective CRM strategy requires the integration of various human, technological and business capabilities.

Scholars in IT have also made progress in this area. Tippins and Sohi (2003) define an IT competency as consisting of: (a) the body of technical knowledge about IT systems, (b) the extent to which the firm uses IT, and (c) the number of IT related artefacts. Coltman et al. (2006) has integrated these components and shown that to be most effective, CRM programs require the orchestration of a combination of resources and capabilities. This work allows us to hypothesise that a superior CRM capability will have a positive effect on market oriented positional advantage.

$H_{1}$ : Organizations with superior CRM capability display a greater propensity to capture market-oriented positions of advantage relative to competitors.

A critical aspect of this model and overall firm success is to establish whether investment in building a CRM capability is a "sensible" thing to do. As Bohling et al., (2006) suggest, success depends upon both the appropriateness of the firm's CRM strategy and the effectiveness of the CRM implementation. However, achieving effective implementation in practice is not easy. Rather, the anecdotal evidence emerging indicates that the ability to execute CRM programs is one of the most formidable challenges to CRM program success. This is true of any IT implementation because it is typically a collective social action that involves the interaction between people, their values, beliefs and work practices. If the "promises" of CRM implementation fail to impress potential beneficiaries, or if they stand to lose as a result of the implementation, then the requisite agreement required may be impossible to reach and/or enforce. Hence, firms must come to terms with the tension between new customer relationship strategies and existing forms, systems and resources.

In the IT literature, scholars have previously used a 'garbage can' metaphor to capture the variety of constraints that inhibit technology execution (Lucas, 2005). However, the use of 
metaphors in this way serves only to confuse matters, and implies the need for further research. Weill (1990) has previously proposed that the capability to convert IT investment into useful outputs is an important mediator. Neo-institutional theory also provides insight by directing us toward issues of institutional feasibility that define what the firm can actually do, as distinct from what the firm would like to do (Carson et al., 1999). This work draws on efficiency concepts developed by Wernerfelt (1984) and Williamson's (1996) work on remediability, to develop a greater understanding of whether certain IT investment programs such as CRM programs are feasible or not.

This literature is relevant to CRM implementation because it: (1) accounts for the uncertainty associated with integrating fragmented silos of customer information; (2) reflects the fact that there are large set up and take down costs; (3) accounts for behavioral change that will underpin any new arrangement; and (4) accounts for the complex organizational interdependencies that will impact on issues (1) - (3).

Hence, the ultimate impact of CRM capabilities on the achievement of a market orientation (and on its profitability) cannot be posited to be positive or negative per se, but is contingent on the ability to execute such a program - a term we label conversion feasibility in this paper. The conversion feasibility premise controversially implies that firms do not face the same choice set, cannot freely elect to follow the "best path", and are limited in their ability to adapt to the environment (Jap \& Anderson, 2003). It is hypothesised that conversion feasibility moderates the link between CRM and market oriented positional advantage.

$\mathrm{H}_{2}$ : When conversion feasibility is high, superior organizations are well positioned to capture market-oriented positions of advantage.

One would reasonably expect that the more the "voice" of the target customer is brought into the organization and acted upon, the better the positional advantage and subsequent 
performance of the business (Day, 1994). All things being equal, a business unit that is more market oriented than its competitors is more likely to out-perform the competition in its target markets. The reasons for this are straightforward. Greater knowledge about what customers want should lead to more effective market targeting, product development and positioning (Hunt \& Morgan, 1995).

However, despite the appeal to scholars in marketing, the fundamental assumption that greater market orientation equals higher performance is far too simplistic and does not hold in many circumstances (Langerak, 2003). One reason for this is the apparent confusion among scholars regarding the meaning of the term market orientation. Narver et al. (2000) argue that a more correct interpretation of market orientation is to divide it into two complementary forms: (1) reactive market orientation, and (2) proactive market orientation. A reactive market orientation emphasises expressed customer needs of which the customer is aware and is similar to the customer-led (Slater \& Narver, 1995) and customer-compelled (Day, 1999) constructs that have been the focus of virtually all the research conducted to date. The second form is proactive market orientation which seeks to satisfy a customer's latent needs. By definition, these are attributes of which the buyer is unaware and is therefore unable to articulate. To date, this area has received little attention and virtually no empirical analysis by marketing scholars has been conducted. We therefore hypothesise that market orientation (both reactive and proactive) will mediate the link between CRM capability and firm performance.

$H_{3 a}:$ Reactive market orientation mediates the relationship between CRM capability and performance $H_{3 b}:$ Proactive market orientation mediates the relationship between CRM capability and performance 
These hypotheses position CRM as a business strategy and company-level philosophy where knowledge about customers and their preferences has implications for the entire organization (Kumar \& Reinartz, 2006). Hence, CRM is not simply an IT solution that is used to acquire and grow the customer base. It involves the adroit combination of human, technology and business related capabilities in an environment that can feasibly support the type of integration required.

\section{INSTRUMENT DEVELOPMENT and MEASURES}

Using the strategic business unit (SBU) as the level of analysis, all scales were developed using an extensive and recursive pre-testing procedure-all item measures are shown in Attachment A along with citation sources. Business performance is central to the information systems field, yet the many ways in which it is measured suggests that both the conceptualization and measurement of performance is an issue. Past studies in IT (Tippins \& Sohi, 2003) suggest that measures of performance need to exhibit three key attributes: (1) they should provide a multidimensional and balanced assessment of performance, (2) they should incorporate a competitive assessment element, and (3) they should address the notion of performance over time. To address attribute (1), a balanced scorecard view of performance (Kaplan and Norton 1996) was applied that includes financial measures (return on investment), customer satisfaction (sales growth), business process improvement (reduction in the cost of transacting with customers), and innovation or success in generating revenue from new products. In respect of attribute (2), we develop some sense of comparativeness by asking respondents to assess performance relative to that enjoyed by key competitors (Birley \& Westhead, 1990). This is important because, taken in isolation, an organization's performance, whether strong or weak, contains only limited meaning. Attribute (3) is addressed by ensuring that all individual assessments of performance were based on the last 
three years. This is necessary to overcome quarterly reporting practices that may fluctuate widely across any given time period.

The level of customer or market orientation is measured according to a behavioural stream of research which describes market orientation in terms of specific behaviours related to the organization-wide generation of market intelligence. This includes current and future customer needs, dissemination of intelligence across departments, and organization-wide responsiveness to it (Kohli \& Jaworski, 1990). Key features in this view are a focus on customers, an emphasis on the specific form of inter-functional coordination, and activities related to information processing. Importantly, Narver et al. (2000) hold that measures of market orientation must take into account the two forms in which customers' needs and solutions exist: expressed (reactive market orientation) and latent (proactive market orientation). All items for the reactive market orientation construct were taken from the MORTN scale (Deshpande \& Farley, 1998), while measures of the proactive market orientation construct were derived from recent work by Narver and Slater (2000).

In accordance with the literature in strategy (Leonard, 1998), marketing (Day and Van den Bulte 2003) and information systems (Bharadwaj, 2000; Tippins \& Sohi, 2003), three itemsmeasured on a seven point scale-were used to establish the higher order construct CRM capability. Importantly, each item required respondents to compare capabilities relative to their direct competition. The importance of this is that the firms' capabilities need to be superior to the competition if they are to contribute positively to competitive advantage. The three measures of customer relating capability they should provide are: (1) skills and experience at converting data to customer knowledge; (2) level of IT infrastructure; and (3) alignment of incentives, customer strategy and structure.

There are many institutional barriers that managers face when deciding to invest in IT. Complementing the remedial efficiency concept has been the contribution by Weill (1990). 
Weill developed a measure of "conversion feasibility" that captures the limitations of all the affected players (customers and partners), the costs of setting up the new arrangement, and the costs of undoing the old arrangement. The construct is based on four types of constraint; top management commitment, experience with IT, user satisfaction, and political turbulence. This approach is in line with recent work by Carson et al. (1999) and Coltman (2006).

Since this line of thinking is relatively new and no existing scales exist, a new scale was created based on four items that capture explicit constraints-sunk costs in equipment and personnel—and implicit constraints facing the firm-embedded political and behavioural complexity (Christensen \& Overdorf, 2000; Coltman et al., 2007; Weill, 1990).

\section{EMPIRICAL MEASUREMENT}

\section{Sample Selection and Collection}

Based on an extensive review of the academic journals, trade reports and pre-test interviews, a decision was made to restrict the range in this study to a cross-sectional sample of business to consumer firms. Business-to-business firms were not the main focus of this study. The primary reason for this is that they are typically characterized by small numbers of customers and a strong reliance on a few key salespeople for most of the communication with clients. Therefore, the opportunity for variance between CRM adoption and subsequent performance is unlikely to be as great in a B2B setting.

Four hundred and fifty companies were then randomly drawn from a commercially available database based on seven broad industry sectors: financial services, insurance, airlines, utilities, telecommunications, hotels and large retailers. The industries selected have in common a moderate to heavy use of CRM technology, a large customer base, and market pressure to differentiate themselves from their competition. This approach was similar to that employed by Reinartz et al. (2004). 
Pre-survey telephone calls were made to each participant to identify whether they would be prepared to participate in the survey or whether they could provide contact details for the most appropriate person in their firm. Several approaches were then used to ensure an adequate response rate. A personalized cover letter and questionnaire was sent to each survey participant. The questionnaire contained a number of incentives: (1) a commitment to provide a strategic report that could be used to benchmark their own organization against industry trends, (2) an offer to attend a free breakfast seminar hosted by Fairfax Business Research and SAP where the survey results would be reported, and (3) the chance to win a $\$ 300$ gift voucher. Reminder emails with the questionnaire attached were also sent to all participants and in some cases these were followed by a phone call a week later. In a final effort to entice a survey response, a reminder was sent along with a short (three-page) CRM-related article intended to provide respondents with a tangible sample of the research objectives.

One hundred executives responded to the questionnaire, yielding a 22 percent response rate. After eliminating responses due to large proportions of missing data, a final sample of 91 cases was obtained. Distribution of responses to the survey was skewed towards the more traditional users of CRM: Finance (40\%), Insurance (9\%), Telecommunications (12\%), Airline (7\%), Hotels/Tourism (6\%), Utilities (6\%), Retail (10\%) and other (9\%). The median firm studied had approximately 300 employees, with the smallest firm having 50 employees and the largest 12,000 . Tests on the distribution of returned questionnaires relative to the sample indicated no significant industry, firm size or respondent position bias.

\section{Measure Validity}

A two-step approach to data analysis was performed that included: (1) a detailed assessment of the measurement model, and (2) an analysis of the relationships between constructs. To ensure the validity of each measure, key informant bias, non-response bias, common method 
bias, convergent validity, and discriminant validity, were examined. For the sake of brevity, only a short summary is provided.

Senior managers were targeted from three functional areas (IT, marketing, and strategy), reducing the impact of key informant bias. To determine the impact of informant bias in the study, t-tests were used to examine differences in the degree of market orientation and performance between top management $(n=34)$ and middle management $(n=48)$. While a slight difference was detected between groups, this difference was not significant for market orientation $(\mathrm{t}=-0.81 \mathrm{p}>0.1)$ and performance $(\mathrm{t}=-0.67 \mathrm{p}>0.1)$. On the basis of these tests, informant bias does not appear to be a concern in this study. Results from a follow-up survey indicate that the risks from non response bias are low. The lack of any "general factor" in the data also indicates a lack of any common method bias. Based on Harman's ex post one-factor test (Podsakoff \& Organ, 1986) 26 distinct factors were needed to explain $81 \%$ of the variance in the measures used, with the largest factor accounting for only $14 \%$ of the variance.

Table 1 displays the descriptive statistics for the construct measures and the results reveal that sufficient range and variance exists in the data. A correlation matrix of the constructs is shown in Table 2. For the reflective constructs, factor analyses of their underlying questionnaire items indicated one dimension for each, making it legitimate to compute Cronbach alphas and to regard them as unitary constructs. All Cronbach alpha scores are above the 0.7 threshold level (Cronbach, 1951). The fact that these scores are all above 0.7 indicates adequate convergent validity for their underlying items. Further, correlation scores within each construct are higher than the correlations between the various constructs, indicating adequate discriminant validity between these constructs.

$<<$ Insert Table 1 here $>>$

$<<$ Insert Table 2 here $>>$ 
Discriminant validity was also assessed by comparing the variance shared by constructs, as measured by the squared correlation between them, with the average variance extracted (AVE) by each construct's measurement items (Fornell \& Larcker, 1981). In other words, the amount of variance captured by the construct (through its indicators) should be demonstrably closer to its measurement items than to another construct. If not, there may be insufficient distinction between two constructs, as measured by the items in this study. The correlation matrix in Table 2 shows that the square root of the construct's AVE-as shown on the diagonal elements-are greater than the corresponding off-diagonal elements. It is thus possible to conclude that each measure is tapping into distinct and different concepts.

\section{RESULTS}

Multiple regression is frequently used to verify hypotheses and detect main and mediation effects. The three sections that follow provide regression results for hypotheses 1-3.

\section{Direct Effect of CRM on Market Orientation}

The results displayed in Table 3 indicate that there is a positive and significant relationship between CRM capability and reactive market orientation $(\beta=0.23 \mathrm{p}<0.01)$ and proactive market orientation $(\beta=0.33 \mathrm{p}<0.01)$. This finding supports hypothesis 1 where organizations with superior CRM capabilities display a greater propensity to capture market oriented positions of advantage relative to competitors. Further, as expected, the direct effect of conversion feasibility is positive and significant in the case of reactive market orientation ( $\beta=$ $0.39 \mathrm{p}<0.01)$ and proactive market orientation $(\beta=0.25 \mathrm{p}<0.1)$. The result appears to imply that proactively oriented companies are less constrained by conversion challenges such as internal politics, organizational behavior and infrastructure costs.

$$
<\text { Insert Table } 3 \text { here }>>
$$

\section{Moderating Effect of Conversion Feasibility on Market Orientation}


Moderated multiple regression (MMR) models were estimated to evaluate hypothesis 2 . MMR is the method of choice for testing hypotheses about moderator effects of categorical variables in a variety of research domains (Aguinis, 2004). To support interpretation, each moderator was converted into a dichotomous variable ( $1=$ high, $0=$ low). The procedure for calculation of all dichotomous variables was to: (1) compute the median score for each moderator, (2) allocate a value of "one" (a high value) to all scores above the median, and (3) allocate a "zero" (a low value) to all scores equal to or less than the median. The main benefit of using dichotomous moderating variables is that it allows power scores to be easily computed for any non-significant findings. Similar results were also obtained when the moderating variable was not dichotomized in accord with Aiken and West's (1991) standardization procedure.

The results reveal that the moderator or interaction effect is in the expected direction for both reactive and proactive market orientation. However, the effect is not significant and therefore hypothesis 2 is not supported.

\section{Mediating Effect of Market Orientation}

In our model, market orientation is said to function as a mediator whenever it accounts for the relation between CRM capability and performance. To evaluate hypothesis 3 and test for mediation, a series of regression models should be estimated (Baron \& Kenny, 1986):

$$
\begin{aligned}
& \mathrm{Y}_{\mathrm{MO}}=\alpha+\beta_{1} * \mathrm{X}_{\mathrm{C}}+e_{\mathrm{i}} \\
& \mathrm{Y}_{\mathrm{P}}=\alpha+\beta_{2} * \mathrm{X}_{\mathrm{MO}}+e_{\mathrm{i}} \\
& \mathrm{Y}_{\mathrm{P}}=\alpha+\beta_{1} \mathrm{X}_{\mathrm{C}}+\beta_{2} \mathrm{X}_{\mathrm{MO}}+e_{\mathrm{i}}
\end{aligned}
$$

The first equation should regress the mediator (market orientation or $\mathrm{X}_{\mathrm{MO}}$ ) on the independent variable (CRM capability or $\mathrm{X}_{\mathrm{C}}$ ). The second should regress the dependent variable (performance or $\mathrm{Y}_{\mathrm{P}}$ ) on $\mathrm{X}_{\mathrm{C}}$ the independent variable. The third equation should regress $Y_{P}$ on both $X_{M O}$ and $X_{C}$. The hypotheses predict that both reactive and proactive market orientation mediate performance. 
Table 4 presents the regression results. The regression models for proactive orientation indicate that: (1) the effect of CRM capability on proactive market orientation is positive and significant $(\beta=0.33 \mathrm{p}<0.001)$, (2) the effect of CRM capability on performance is positive and significant $(\beta=0.28 \mathrm{p}<0.000)$, and (3) both $\mathrm{CRM}$ and proactive market orientation on performance is positive and significant. Additionally, all conditions hold in the predicted direction and the effect of CRM capability in the third equation $(\beta=0.22 \mathrm{p}<0.08)$ was less than in the second $(\beta=0.28 \mathrm{p}<0.001)$. Although significant, the impact of proactive market orientation on performance is accepted at a level of $\mathrm{p}<0.1$, which is higher than the conventional 0.05 level. Nevertheless, these results provide statistical verification that proactive market orientation partially mediates performance-hypothesis $3_{\mathrm{b}}$ is supported.

The results for reactive orientation indicate that: (1) the effect of CRM capability on reactive market orientation is positive and significant $(\beta=0.21 \mathrm{p}<0.05),(2)$ the effect of CRM capability on performance is positive and significant $(\beta=0.28 \mathrm{p}<0.001)$, and (3) only CRM capability is significant $(\beta=0.28 \mathrm{p}<0.001)$. The effect of reactive market orientation on performance was negative and not significant $(\beta=-0.01 \mathrm{p}>0.1)$. Thus hypothesis $3_{\mathrm{a}}$ was not supported for reactive market orientation. However, all mediators are likely to be measured with error and therefore produce an underestimate of the mediating effect and an overestimate of the independent variable effect (Baron \& Kenny, 1986).

$$
<<\text { Insert Table } 4 \text { here }>>
$$

\section{DISCUSSION}

The results reveal that CRM capability is stronger on proactive market orientation than it is on reactive market orientation ( 0.33 versus 0.23$)$. This finding is consistent with reports that CRM is best aligned with a strategy that puts a premium on superior market sensing and customer analysis. This study has also demonstrated empirically that the positive mediating effect of proactive market orientation on performance implies a shift in emphasis for 
managers from "responsive market orientation"-where a business responds to the expressed needs of its target customers - to a proactive strategy based on modelling latent customer needs. In support of this point the data is quite clear and indicates that responsive tactics are losing their effectiveness because customers expect companies to do more that just respond to expressed needs.

There are several possibilities for why this might be the case. Some observers have suggested that being market oriented may detract from innovativeness (Bethron et al., 1999), lead to myopic R\&D (Frosch, 1996), or disrupt business activity (MacDonald, 1995). Those that support an innovation based orientation (Christensen \& Bower, 1996; Christensen, 2000) hold that firms fail to see the impact of disruptive technologies because they listen too closely to their customers. Intuition suggests that if a customer can tell a particular firm what they require, then they can also tell other firms what they want; creating competitive pressures which ultimately drive down prices and subsequent profitability. On the other hand, if a customer cannot tell you what they want then they cannot tell your competitors what they want. As a result, the company that can anticipate their customer's needs, without relying on customer feedback, may reduce the perils of market competition. Indeed the data provides unambiguous support for this type of orientation will yield superior performance. The implication for management is that CRM programs can be particularly valuable if attention is directed towards using these programs to identify customer needs that are latent and unarticulated.

Our inability to find a significant moderating effect for conversion feasibility has two implications: (1) conversion feasibility is not a moderator, or (2) a lack of statistical power may inhibit the ability to detect an effect. Low power and effect sizes are not uncommon in this type of field research and there are many reasons why this may be the case; sample size, multicollinearity, and measurement error, can all adversely influence the power of this test. In 
his book titled "Estimating Interaction/Moderating Effects Using Multiple Regression," Hermon Aguinis (2004) provides an online "MMRPower" effect size test. This is a rigorous test and indicates effect size for the dichotomous measure conversion feasibility on reactive market orientation $\left(f^{2}=0.08\right)$ and proactive market orientation $\left(f^{2}=0.07\right)$. Assuming that correlations between items in this study remain constant, one would need to increase the sample size by a further 1000 data points to generate a suitable power level of 0.8 .

Several industry and firm specific control measures were used to detect further patterns in the data. First, to control for the possibility of a size effect, organizational size was measured by number of employees. This control has no effect on the measures of market orientation or performance. Second, to control for the possibility of variance across different industry sectors, four dummy variables were used to represent five broad industry sectors. No uniform pattern in the data was evident to suggest that an industry effect exists. The only exception was the business service sector where a positive and significant impact on reactive market orientation was found. This finding is to be expected, as the essence of this sector is customer service. Overall, the lack of an industry effect is by no means conclusive and may be attributable to insufficient power.

Lastly, customer relationship controls were used to identify customer preferences for a particular kind of relationship. The three dummy variables used were acquaintance, friend and true partner, where the base case was no relationship at all. These different categories of relationship maturity are based on work by Johnson and Selnes (2004) that categorize relationships on the basis of relationship maturity. The results reveal negative and significant results as one would expect. In other words, companies with large proportions of customers that do not have the time, energy or motivation to form deep customer relationships-where customers are classified as acquaintances or friends-are unlikely to gain competitive advantages through market orientation strategies, either reactive or proactive in focus. This 
finding underscores the need for future research to differentiate relationships on the basis of how value is created and to link value creation in relationship segments to overall firm performance.

\section{CONCLUSION and IMPLICATIONS}

CRM has become a buzzword of late, and like all new initiatives, suffers when it is poorly understood, improperly applied and incorrectly measured and managed. In this study, we show why CRM programs can be successful and what capabilities are required to support success. The first implication for managers is that CRM programs should be directed towards customer value that competitors cannot match. On this point the results are quite clear. High performing companies base their success on proactive rather than reactive orientations. CRM programs that support identification of latent or unarticulated customer demand are well positioned to add real business value and imply a positive future for CRM software applications, data mart and data warehouse technologies such as those offered by the SAS Institute and NCR Teradata. These applications have made it possible for pharmaceutical firms (Forrester Research, 2002), financial institutions (Kumar \& Reinartz, 2006) and retailers (Humby, 2002) to gather vast amounts of customer data, analyze, interpret and utilize it in constructive ways.

As true of any study, this research has limitations that qualify the findings and present opportunities for future research. For example, it is possible that those companies that have been working longer on their CRM programs are, in turn, among the better performing companies. These companies have been able to reinvest profits into CRM resource development to ensure success. The inability to capture this effect is a common limitation of cross-sectional designs, and longitudinal studies would provide greater insight into this effect. A larger sample size would provide greater power for moderation and mediation tests and enable "out of sample" validation to be conducted to enhance external validity. However, the 
ability to attain sufficient sample size and improved power is not simple. The standard deviation, correlation and item reliability scores detected in this study make it difficult to obtain adequate power (i.e., 0.8) as there are simply not enough companies using CRM in the Australian population. Future work will seek to extend the study beyond Australia.

The ultimate litmus test of an organization's investment in CRM is its ability to improve the way it performs against the competition. This requires that firms know not only how their company stands on a host of performance dimensions but that it can roughly benchmark itself against a correct set of peers. The multidimensional comparative nature of performance also presents many challenges for scholars and implies that performance should be measured using alternative approaches-financial or non-financial; accounting or market based and objective or subjective. Hence, future work would benefit from alternative measures of performance to the measures used in this study, as no single measure is superior in the whole.

Finally, this study compliments prior work that has investigated the way CRM affects customer satisfaction (Mithas et al., 2005), customer service processes (Ray et al., 2005) and company performance (Reinartz et al., 2004). In particular, this study provides a fresh perspective by investigating the impact of CRM on positional advantage. Furthermore, the study has shown that CRM programs are best viewed as a higher order capability that requires the orchestration of human, technological and business capabilities. By integrating three schools of thought—capabilities, market orientation and conversion feasibility—this study provides a unique view of CRM performance that is both managerially relevant and theoretically important to explain CRM program success.

\section{REFERENCES}

Aguinis, H. (2004). Regression Analysis for Categorical Moderators. New York: Gilford Publications.

Amit, R., \& Shoemaker, P. J. H. (1993). Strategic Assets and Organizational Rent. Strategic Management Journal, 14(1), 33-46.

Barney, J. B. (1991). Firm Resources and Sustained Competitive Advantage. Journal of Management, 17(1), 19120 . 
Baron, R. M., \& Kenny, D. A. (1986). The Moderator-Mediator Variable Distinction in Social Psychological Research: Conceptual, Strategic and Statistical Considerations. Journal of Personality and Social Psychology, 51(6), 1173-1182.

Barua, A., Kriebel, C. H., \& Mukhopadhyay, T. (1995). Information Technology and Business Value: An Analytic and Empirical Investigation. Information Systems Research, 6(1), 3-23

Bethron, P., Hulbert, J., \& Pitt, L. (1999). To Serve of Create? Strategic Orientations Towards Customers and Innovation. California Management Review, 42(1), 37-58.

Bharadwaj, A. S. (2000). A Resource-Based Perspective on Information Technology Capability and Firm Performance: An Empirical Investigation. MIS Quarterly, 24(1), 169-196.

Birley, S., \& Westhead, P. (1990). Growth and Performance Contrasts Between 'Types' of Small Firms. Strategic Management Journal, 11(7), 535-557.

Bohling, T., Bowman, D., LaValle, S., Mittal, V., Narayandas, D., Ramani, G., \& Varadarajan, R. (2006). CRM Implementation: Effectiveness Issues and Insights. Journal of Services Research, 9(2), 184-194.

Carr, N. (2003). IT Doesn't Matter. Harvard Business Review, 81(5), 5-12.

Carson, S. J., Devinney, T. M., Dowling, G. R., \& John, G. (1999). Understanding Institutional Designs Within Marketing Value Systems. Journal of Marketing, 63(Special Issue), 115-130.

Chan, Y. E. (2000). IT Value: The Great Divide Between Qualitative and Quantitative and Individual and Organizational Measures. Journal of Management Information Systems, 16(4), 225-261.

Christensen, C. J., \& Bower, J. (1996). Customer Power, Strategic Investment, and the Failure of Leading Firms. Strategic Management Journal, 17(3), 197-218.

Christensen, C. M. (2000). After the Gold Rush. Innosight.

Christensen, C. M., \& Overdorf, M. (2000). Meeting the Challenge of Disruptive Change. Harvard Business Review, 78(2), 67-76.

Coltman, T., Devinney, T. M., \& Midgley, D. F. (2007). E-Business Strategy and Firm Performance: A Latent Class Assessment. Journal of Information Technology, 21(4), 1-15.

Coltman, T. R. (2006). Where are the Benefits in CRM Technology Investment? Hawaii International Conference on System Sciences (HICSS), Hawaii, January 3-6.

Cronbach, L. J. (1951). Coefficient Alpha and the Internal Structure of Tests. Psychometrika, 16(3), 297-334.

Davenport, T. H. (1993). Process Innovation: Reengineering Work through Information Technology. Boston, Mass.: Harvard Business School Press.

Davenport, T. H., Harris, J. G., Long, D. W. D., \& Jacobson, A. L. (2001). Data to Knowledge to Results: Building and Analytic Capability. California Management Review, 43(2), 117-137.

Day, G. (1999). Misconceptions About Market Orientation. Journal of Market-Focused Management, 4(1), 5-16.

Day, G. S. (1994). The Capabilities of Market-Driven Organizations. Journal of Marketing, 58(4), $37-52$.

Day, G. S. (2002). Winning the Competition for Customer Relationships. Pennsylvania: The Wharton School.

Day, G. S. (2003). Creating a Superior Customer-Relating Capability. MIT Sloan Management Review, 44(3), 77-82.

Day, G. S., \& Van den Bulte, C. (2002). Superiority in Customer Relationship Management: Consequences for Competitive Advantage and Performance.Unpublished manuscript, Cambridge MA.

Day, G. S., \& Hubbard, K. J. (2003). Customer Relationships Go Digital. Business Strategy Review, 14(1), 1726.

Day, G. S., \& Wensley, R. (1988). Assessing Advantage: A Framework for Diagnosing Competitive Superiority. Journal of Marketing, 52(4), 1-20.

Deshpande, R., \& Farley, J. (1998). Measuring Market Orientation: Generalization and Synthesis. Journal of Market-Focused Management, 2(3), 213-232.

Deshpande, R., Farley, J. U., \& Jr, F. E. W. (1993). Corporate Culture, Customer Orientation, and Innovativeness in Japanese Firms: A Quadrad Analysis. Journal of Marketing, 57(1), 22-27.

Drucker, P. F. (1954). The Practice of Management. New York: Harper and Row. 
Dutta, S., Narasimhan, O., \& Rajiv, S. (2005). Conceptualising and Measuring Capabilities: Methodology and Empirical Application. Strategic Management Journal, 26(3), 277-285.

Fornell, C., \& Larcker, D. F. (1981). Evaluating Structural Equation Models with Unobservable Variables and Measurement Error. Journal of Marketing Research, 18(1), 39-50.

Fornell, C., Mithas, S., III, F. V. M., \& Krishnan, M. S. (2006). Customer Satisfaction and Stock Prices: High Returns, Low Risk. Journal of Marketing, 70(1), 3-14.

Frosch, R. (1996). The Customer for R\&D Is Always Wrong. Research Technology Management. 39(6), $22-27$.

Grabner-Kraeuter, S., \& Moedritscher, G. (2002). Alternative Approaches Toward Measuring CRM Performance. Paper presented at the Sixth Research Conference on Relationship Marketing and Customer Relationship Management, Atlanta, June 9-12.

Grant, R. M. (1996). Toward a Knowledge-Based Theory of the Firm. Strategic Management Journal, 38(5), 109-122.

Humby, C. (2004). Tesco. Dunnhumby Associates, http://www.dunnhumby.co.uk.

Hunt, S. D., \& Morgan, R. M. (1995). The Comparative Advantage Theory of Competition. Journal of Marketing, 59(2), 1-15.

Hunter, S., Kobelsky, K., \& Richardson, V. J. (2003). Information Technology and the Volatility of Firm Performance.Unpublished manuscript, Boston.

InfoWorld. (2001). CTO Network Year-in-Review Survey. Available: www.infoworld.com/articles/hn/xml/01/12/24/011224hnyearend.xml, 1st December.

Jap, S., \& Anderson, E. (2003). Testing the Life-Cycle Theory of Interorganizational Relations: Do Performance Outcomes Depend on the Path Taken?Unpublished manuscript, Fontainebleau.

Jaworski, B. J., \& Kohli, A. K. (1993). Market Orientation: Antecedents and Consequences. Journal of Marketing, 57(3), 53-70.

Johnson, M. D., \& Selnes, F. (2004). Customer Portfolio Management: Toward a Dynamic Theory of Exchange Relationships. Journal of Marketing, 68(4), 1-17.

Kale. (2004). CRM Failure and the Seven Deadly Sins. Marketing Management, 13(5), 42-46.

Kaplan, R., \& Norton, D. (1996). The Balanced Scorecard. Boston: Harvard Business School Press.

Kohli, A. K., \& Jaworski, B. J. (1990). Market Orientation: The Construct, Research Propositions, and Managerial Implications. Journal of Marketing, 54(4), 1-8.

Kohli, R., \& Devaraj, S. (2003). Measuring Information Technology Payoff: A Meta Analysis of Structural Variables in Firm-Level Empirical Research. Information Systems Research, 14(2), 127-145.

Kumar, V., \& Reinartz, W. J. (2006). Customer Relationship Management: A Databased Approach. New Jersey: John Wiley \& Sons.

Langerak, F. (2003). An Appraisal of Research on the Predictive Power of Market Orientation. European Management Journal, 21(4), 447-464.

Leonard, D. (1998). Wellsprings of Knowledge: Building and Sustaining the Sources of Innovation. Boston. MA: Harvard Business School Press.

Lucas, H. C. (2005). Information Technology: Strategic Decision Making for Managers. New York: John Wiley.

MacDonald, S. (1995). Too Close for Comfort: The Strategic Implications of Getting Close to the Customer. California Management Review, 37(4), 8-27.

Mata, F. J., Fuerst, W. L., \& Barney, J. B. (1995). Information Technology and Sustainable Competitive Advantage: A Resource Based Analysis. MIS Quarterly, 19(4), 487-505.

Melville, N., Kraemer, K., \& Gurbaxani, V. (2004). Information Technology and Organizational Performance: An Integrative Model of IT Business Value. MIS Quarterly, 28(2), 283-322.

Mithas, S., Krishnan, M. S. and Fornell, C. (2005). Journal of Marketing, 69, 201.

Narver, J., \& Slater, S. (1990). The Effect of a Market Orientation on Business Profitability. Journal of Marketing, 54(10), 20-35 
Narver, J. C., Slater, S. F., \& MacLachlan, D. L. (2000). Total Market Orientation, Business Performance, and Innovation (Working Paper 00-116): Marketing Science Institute.

Otley, D. (2002). Measuring Performance: The Accounting Perspective. In A. Neely (Ed.), Business Performance Measurement: Theory and Practice. Cambridge, UK: Cambridge University Press.

Parvatiyar, A., \& Sheth, J. N. (2001). Conceptual Framework of Customer Relationship Management. In J. N. Sheth \& A. Parvatiyar \& G. Shainesh (Eds.), Customer Relationship Management - Emerging Concepts, Tools and Applications (pp. 3-25). New Delhi, India: Tata/McGraw-Hill.

Payne, A., \& Frow, P. (2005). A Strategic Framework for CRM. Journal of Marketing, 69(10), 167-176.

Piccoli, G., \& Ives, B. (2005). IT-Dependent Strategic Initiatives and Sustained Competitive Advantage: A Review and Synthesis of the Literature. MIS Quarterly, 29(4), 747-777.

Podsakoff, P., \& Organ, D. (1986). Self Reports in Organizational Research: Problems and Prospects. Journal of Management, 12(4), 531-544.

Powell, T., \& Dent-Medcalfe, A. (1997). Information Technology as Competitive Advantage: The Role of Human, Business, and Technology Resources. Strategic Management Journal, 18(5), 375-405.

Priem, R. L., \& Butler, J. E. (2001). Is the Resource-Based View a Useful Perspective For Strategic Management Research? Academy of Management Review, 26(1), 22-40.

Ray, G., Muhanna, W. A., \& Barney, J. B. (2005). Information Technology and the Performance of the Customer Service Process: A Resource-based Analysis. MIS Quarterly, 29(4), 625-653.

Reichheld, F., \& Teal, T. (1996). The Loyalty Effect. Boston, MA: Harvard Business School Press.

Reinartz, W., Krafft, M., \& Hoyer, W. D. (2004). The Customer Relationship Management Process: Its Measurement and Impact on Performance. Journal of Marketing Research, 41(3), 293-313.

Reinartz, W., \& Kumar, V. (2000). On the Profitability of Long-Life Customers in a Noncontractual Setting. Journal of Marketing, 64(3), 17-35.

Research, F. (2002). Pharma CRM Analytical Cure: Forrester Research Inc.

Rigby, D. K., Reichheld, F. F., \& Schefter, P. (2002). Avoid the Four Perils of CRM. Harvard Business Review, 80(2), 101-109.

Rivard, S., Raymond, L., \& Verreault, D. (2006). Resource-Based View and Competitive Strategy: An Integrated Model of the Contribution of Information Technology to Firm Performance. Journal of Strategic Information Systems, 15, 29-50.

Ryals, L., \& Payne, A. (2001). Customer Relationship Management and Financial Services: Towards Information Enabled Relationship Marketing. Journal of Strategic Marketing, 9(1), 1-25.

Santhanam, R., \& Hartono, E. (2003). Issues in Linking IT Capability to Firm Performance. MIS Quarterly, $27(1), 125-153$.

Sethi, V., \& Carraher, S. (1992). Developing Measures for Assessing the Organizational Impact of Information Technology: A Comment on Mahmood and Soon's Paper. Decision Sciences, 24(4), 867-877.

Slater, S. F., \& Narver, H. C. (1995). Market Orientation and the Learning Organization. Journal of Marketing, 59(3), 63-74.

Slater, S. F., \& Narver, J. C. (2000). Intelligence Generation and Superior Customer Value. Journal of Academy of Marketing Science, 28(1), 120-127.

Teece, D. J., Pisano, G., \& Shuen, A. (1997). Dynamic Capabilities and Strategic Management. Strategic Management Journal, 18(7), 509-533.

Tippins, M. J., \& Sohi, R. S. (2003). IT Competency and Firm Performance: Is Organizational Learning A Missing Link? Strategic Management Journal, 24, 745-761.

Wade, M., \& Holland, J. (2004). The RBV and IS Research: Review, Extension and Suggestions for Future Research. MIS Quarterly, 28(1), 107-142.

Watjatrakul, B. (2005). Determinants of IS Sourcing Decisions: A Comparative Study of Transaction Cost Theory versus the Resource-based View. Journal of Strategic Information Systems, 14(4), 389-415.

Weill, P. (1990). Do Computers Pay Off? A Study of Information Technology Investment and Manufacturing Performance. Washington: ICIT Press. 
Wernerfelt, B. (1984). A Resource-Based View of the Firm. Strategic Management Journal, 5(2), 171-181.

Williamson, O. E. (1996). The Mechanisms of Governance. New York: Oxford University Press.

Williamson, O. E. (1999). Strategy Research: Governance and Competence Perspectives. Strategic Management Journal, 20(12), 1087-1108.

Zablah, A. R., Bellenger, D. N., \& Johnston, W. J. (2003). Customer Relationship Management: An Explanation of Its Domain and Avenues for Future Inquiry. In M. Kleinaltenkamp \& M. Ehret (Eds.), Relationship Marketing, Customer Relationship Management and Marketing Management: Co-OperationCompetition-Co-Evolution (Vol. 115-124). Berlin: Freie Universitat Berlin.

Zhu, K. (2004). The Complementarity of Information Technology Infrastructure and E-Commerce Capability: A Resource-Based Assessment of Their Business Value. Journal of Management Information Systems, 21(1), 167.

Zhu, K., \& Kraemer, K. L. (2002). e-Commerce Metrics for Net-enhanced Organizations: Assessing the Value e-Commerce to Firm Performance in the Manufacturing Sector. Information Systems Research, 13(3), 275-296.

\section{ACKNOWLEDGEMENTS}

This research has been supported by the Centre for Corporate Change at the Australian Graduate School of Management and the Centre for Business Services Science at the University of Wollongong. The study has also benefited by financial support from Fairfax Business Research and SAP 


\section{Appendix A: Construct Items}

\begin{tabular}{|c|c|c|}
\hline Construct & Description & References \\
\hline \multirow[t]{5}{*}{ Performance } & $\begin{array}{l}\text { For each performance category below state the highest performer in } \\
\text { your industry. Relative to this competitor, how has your business } \\
\text { performed over the last three years: (Five point scale from Far Better } \\
\text { to Much Worse) }\end{array}$ & $\begin{array}{l}\text { (Sue Birley \& Paul } \\
\text { Westhead, 1990; } \\
\text { Kaplan \& Norton, } \\
\text { 1996; Tippins \& Sohi, } \\
\text { 2003; Wade \& } \\
\text { Holland, 2004) }\end{array}$ \\
\hline & Financial - Return on investment (after tax) & \\
\hline & Customer Satisfaction - Sales growth (revenue turnover) & $\begin{array}{l}\text { (Slater \& Narver, } \\
\text { 2000) }\end{array}$ \\
\hline & Business Process - Reduction in cost of transacting with customers & $\begin{array}{l}\text { (Kohli \& Devaraj, } \\
\text { 2003) }\end{array}$ \\
\hline & Innovation - Success at generated revenue from new products & (Otley, 2002) \\
\hline $\begin{array}{l}\text { Market } \\
\text { Orientation }\end{array}$ & $\begin{array}{l}\text { Taking the perspective of your most profitable customer segment, how } \\
\text { would they compare your business to your three nearest competitors } \\
\text { on the following attributes? (Five point scale from Least/Worst to }\end{array}$ & $\begin{array}{l}\text { (Jaworski \& Kohli, } \\
\text { 1993; Narver \& Slater, } \\
\text { 1990) }\end{array}$ \\
\hline
\end{tabular}

\section{Most/Best)}

\section{Reactive Orientation}

Least/most responsive to individual customer needs

Most/easiest to do business with

Worst/best at sharing customer experiences across business functions Least/most trusted

Worst/best at helping customers to help themselves

Worst/best at driving objectives by customer satisfaction

\section{Proactive Orientation}

Worst/best at discover unarticulated (latent) customer needs

Worst/best at predicting new market developments

Worst/best at brainstorming how customers might better use products and services

CRM

Capability

Compared to your direct competitors, how do you rate your

organization (Seven point scale from The Worst to The Leader)

Skills and experience at converting data to customer knowledge

IT infrastructure

Organizational architecture (i.e., alignment of incentives, customer strategy and structure)

Conversion Feasibility
Please indicate your extent of agreement with the issues stated below (Five point scale from Strongly disagree to Strongly agree) We have complex processes in place that make integration of customer data a difficult proposition ( $\mathrm{R}$ )

When deciding amongst strategic alternatives like CRM, political influence \& parochial interest play a crucial role (R)

Multiple units are/would be affected adversely by the deployment of a new customer relationship programs $(\mathrm{R})$

My organization is well prepared to implement a fully integrated customer information system

Note: items with $(\mathrm{R})$ indicate reverse coding. These items were converted for subsequent analysis.
(Deshpande, Farley, \& Jr, 1993)

(Narver et al., 2000)

(Day, 2003; Teece et al., 1997)

(Davenport, Harris, Long, \& Jacobson, 2001)

(Bharadwaj, 2000; Reinartz et al., 2004) (Day \& Hubbard, 2003)

(Christensen \& Overdorf, 2000; Coltman, 2006; Weill, 1990) 
